高分子铪文集 (Kobunshi Ronbunshu), Vol. 36, No. 4, pp. 249-256 (Apr., 1979)

\title{
エチレンービニルアルコール共重合体からなる 人工罗臑用透析膜の製膜条件と膜性能の検討*
}

\author{
山下 藏*1・長田 司郎*1・高倉 孝一年
}

(受付 1978 年 12 月 5 日・蔳査終了 1979 年 1 月 30 日)

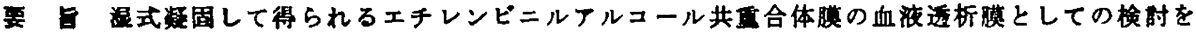

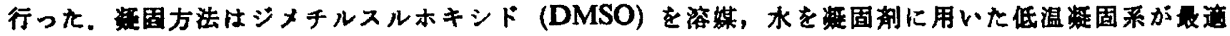

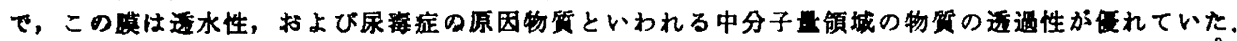

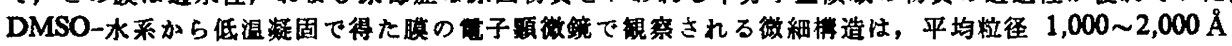

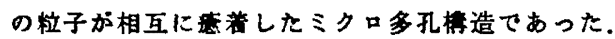

\section{1 緒 㝘}

今日に至るまで，血液透析膜としてはセルロース系の 膜が一般的に使用されてきたが，近年，血液中の势性物 質が明碓にされるに能い，より選択透過性の辰れた膜が 必要とされるよらになった。

ところで，血液透析䠑として利用されるためには，次 の諸性質を满足することが重要である。

（1）含水時の膜強度が人工堅腊用透析膜としての使 用に耐光5る。

(2)遮の造水性を有する.

（3）尿素など低分子量の代謝物質，および尿毒症の 原因物質と考えられる分子量 500〜5,000 程度の中分子 量領域の物質透過が優れており，物質透過性における分 子晋传存性が小さい.

（4）血液音合性が良好である.

このような要件にあった膜を開発するために，今まで 合成高分子を用いて数多くの研究がなされてきた，例え ば, ボリビニルアルコール (PVA)1),2), ボリフクリロニ トリルタ, ボリメチルメタクリレード, ポリ-2ーヒドロ キシエチルメタクリレード, ポリエーテルウレタン゚, ポリエーテルエステルの, ポリエーテルカーボネートク, ボリビニルビロリドン2)などが举げられる。しかしこ れらの中で二，三のものが実用化されたにすぎない．特 に親水性高分子の场合には，膜の含水率の增大とともに 透過性が大きなるが，反面，機械的強度は低下する。 したがって，親水性ボリマーを素材にした选析膜では，透

*本研究を「ェチレンービニルアルコール共重合体か

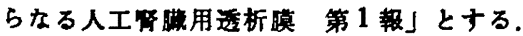

*1 (株) クラレ中央研究所 $(-710$ 合数市酒津青江山 2045-1)
過性能と機械的強度がつり合いよく㑑れたものを得るこ とが困難であり，このことが実用化の障害になっている 場合が注とんどである． PVA の場合は結晶性高分子で あるため，特に，含水時の機械的強度が他の親水性高分 子に比交して恳れている特性を有する，しかし，PVA が本質的に水可容性であるので, 溶出物の点などで, 生 体に用いる場合問題があり，実用化が阻まれている。 こで，我々は水に不溶で，かつ，PVA の長所を兼ねそ なえている親水性高分子, エチレンービニルフルコール (EVA) 共重合体について，血液透析膜としての可能性 を検討した結果，上述の諸要求をほぼ满足できる良好な 透析膜が得られることが分かった。

本報では，製膜法括よび条件，膜の機械的性質と微細 標造, in vitroに护ける血液暗合性について検討した結 果を報告する。

\section{2 实倹}

\subsection{EVA 共百合体の再けん化}

エチレンと酢酸ビニルを高左下，オートクレーブ中で ラシカル共重合させ, これを，けん化して得られた EVA 共重合体を $n$-プロパノールと皮の混合溶媒に再溶 解し，フルカり存在下 $60^{\circ} \mathrm{C}$ で 7 時間加温して再けん化 した後, 水に再沈殿させ完全けん化 EVA 共重合体を得 た。この共重合体のけん化度は $99.9 \mathrm{~mol} \%$ 以上であっ た.

\subsection{EVA 共百合体の溶解性と沈臤温度の测定}

$200 \mathrm{ml}$ のフラスコ中に $20 \mathrm{~g}$ の EVA 共重合体と $80 \mathrm{~g}$ の浴媒を入れ， $100^{\circ} \mathrm{C} て 55$ 時間, 挰拌して溶解させた. このとき得られたボリマー溶液が，肉眼覞察で透明な場 合には EVA 共重合体河溶であると判定した。

沈殿温度は $1 \mathrm{~g}$ の EVA 共重合体と $4 \mathrm{~g}$ の溶媒を試 
鍳管中に封入して $200^{\circ} \mathrm{C} て ゙ 1$ 時間加温溶解後, 5 分間 に $1^{\circ} \mathrm{C}$ の䙵合で温度を降下し，肉眼により濁りが観察 された温度をもって沈股温度とした。

\section{3 膜}

EVA 共重合体の $20 \%$ (重量)溶液を $90^{\circ} \mathrm{C} て ゙ 1$ 時間 加温後, $40^{\circ} \mathrm{C}$ に保ち, 約 $40^{\circ} \mathrm{C}$ に保温されたガラス板 上にナイフコーターを用いて流延した。 これを速やかた 所定温度の㠜固液中に 2 3 分间浸せきして凝固させ， ガラス板より膜をはく奞して含水 EVA 共重合体膜を得 た，又，製膜機を用い，ダイスから直接ポリマー溶液を 凝固液中に押し出して製膜した。

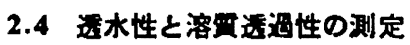

水の透過性 $K, K^{\prime}$ は式 (1)，(2)Kより算出した。

$$
K=V L \eta / t \cdot A \cdot \Delta P \quad\left(\mathrm{~cm}^{2}\right)
$$

$$
K^{\prime}=V / t \cdot A \cdot \Delta P\left(\mathrm{ml} / \mathrm{m}^{2} \cdot \mathrm{h} \cdot \mathrm{mmHg}\right)
$$

$V$ ，透過した水の体䅡 $\left(\mathrm{cm}^{3}\right) ; L$, 膜厚 $(\mathrm{cm}) ; \eta$ ，水の 粘度 $(\mathrm{g} / \mathrm{cm} \cdot \mathrm{s}) ; t$, 時間 $(\mathrm{s}) ; A$, 膜面積 $\left(\mathrm{cm}^{2}\right) ; \Delta P$, 测定任力 (dyn $\left./ \mathrm{cm}^{2}\right)$

容貿の透過性 $D, P_{0}$ は式 (3)，(4) により算出した。

$$
\begin{gathered}
D=\frac{L}{\left(1 / V_{1}+1 / V_{2}\right) A t} \ln \frac{1-C_{2} / C_{1}}{1+\left(V_{2} / V_{1}\right)\left(C_{2} / C_{1}\right)} \\
\left(\mathrm{cm}^{2} / \mathrm{s}\right) \\
P_{0}=\frac{\ln \left(\Delta C_{\left.\left(t^{\prime}\right) / \Delta C_{\left(t^{\prime}\right)}\right)}\right.}{A\left(1 / V_{1}+1 / V_{2}\right)\left(t^{\prime \prime}-t^{\prime}\right)} \quad(\mathrm{cm} / \mathrm{min})
\end{gathered}
$$

$L$, 膜厚; $A$, 透析膜面䅡; $C_{1}, C_{2}, t$ 秒後の各々の七 ル中の溶質港度; $V_{1}, V_{2}$, 七ル容積; $\Delta C_{\left(t^{\prime}\right)}, \Delta C_{\left(t^{\prime \prime}\right)}$, 各々のセル中の $t^{\prime}$ と $t^{\prime \prime}$ 後の溶質湜度の差

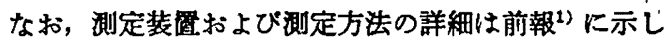
た.

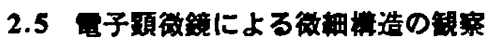

含水膜を含水率が $1 \%$ 以下のアセトンに浸せき後,

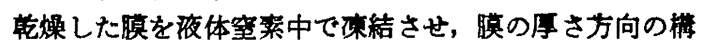
造が锶察できるよらに膜を破断した。この表面に $100 \AA$ の金蒸着を行い，走查型電子䫒微鏡で微細满造を锠察し た. 走査型䉓子影微鏡は日本電子(株) 裂の JSM-2 型, 又は(株)日立製作所製の HFS-2 型を用いた。

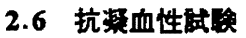

犬の ACD 血夜を用いて今井ら より行った，抗凝血性を定量的に表示するために次式を 用いた， $T_{t}$ 值が小さいほど，抗凝血性が優れているこ とを示す。

$$
\begin{aligned}
T_{t}= & \frac{t \text { 分後に試料上で形成した凝固血液の重量 }}{\text { ガラス板上で最䅂的に形成した凝固血液の重量 }} \\
& \times 100
\end{aligned}
$$

\section{3 桔果と考察}

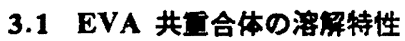

EVA 共重合体の最適溶媒を決定するに当たり，溶解 度バラメーターっおよび沈殷温度を指標にして探索した。

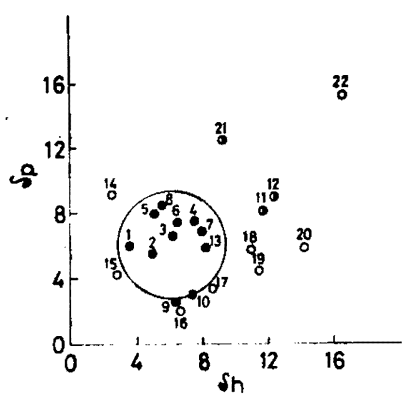

Fig. 1. Solubility region of EVA-33 copolymer: -, soluble; $O$, insoluble (at room temperature); C, soluble (above $35^{\circ} \mathrm{C}$ ); $1, N$-methylpyrrolidone; 2, $N, N$-dimethylacetamide (DMAc); 3, DMAc/ $\mathrm{H}_{2} \mathrm{O}$ ( $90 / 10$ by vol); $4, \mathrm{DMAc} / \mathrm{H}_{2} \mathrm{O}(80 / 20$ by vol); 5 , dimethyl sulfoxide (DMSO); 6, DMSO/MeOH ( $80 / 20$ by vol); $7, \mathrm{DMSO} / \mathrm{MeOH}$ ( $50 / 50$ by vol); 8, 2-pyrrolidone; 9, $m$-cresol; 10 , phenol; $11, n$ propanol/ $\mathrm{H}_{2} \mathrm{O}\left(60 / 40\right.$ by vol); $12, \mathrm{MeOH} / \mathrm{H}_{2} \mathrm{O}(70 /$ 30 by vol); 13 , formic acid; 14, nitromethane; 15, pyridine; 16, cyclohexanol; 17, n-propanol; 18, MeOH; 19, propylene glycol; 20, glycerol; $21, N, N$-dimethylformamide (DMF); 22, water.

まず，ェチレン含有羟が $33 \mathrm{~mol} \%$ の EVA 共重合体 (以下 EVA-33 と略す) の稙々の溶媒に対する溶解性に ついて湌討しこれを二次元のハンセンの溶解度バラメ ーター因" (Fig. 1) に示した。縦軸に溶解度バラメータ

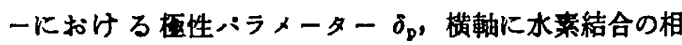
互作用を表すバラメーター $\delta_{\mathrm{n}}$ をとってある. $\left(\delta^{2}=\delta_{\mathrm{a}}{ }^{2}+\right.$ $\delta_{\mathrm{p}}{ }^{2}+\delta_{\mathrm{h}}{ }^{2}, \delta_{\mathrm{d}}$ : 分散力ハララメーター) Fig. 1 Kおいて円 内が EVA 共重合体が室温で可溶な領域を示しており， この円内に位置する称々の溶, および円外の $35^{\circ} \mathrm{C}$ 以 上で可溶な溶媒の中から EVA の最滰溶媒を見いだす模 討を行った。 ここで用いた溶媒で，EVA-33に対する 良溶媒のる値 ${ }^{10}$ は 10.8〜13 の箅囲にあった。

次に，EVA-33 の種々の溶媒に対する溶解性を比故 するために DMSO, フルコール, ジメチルホルムフミ ドお゙よひこれらの溶媒と水との混合溶媒に护沈股 温度について検討した.この結果を Fig. 2 に示す。 DMSO-水系では，水の含有量が增大すると沈股温度は 上界する傾向にあったが，他の含水溶媒系においては， ある混合比によって沈殷温度は極小值を示した， EVA 共重合体中のエチレン含有率之種々の溶媒に対する容解 性の関係を調へるために, DMSO, ジメチルホルムフミ F (DMF), ジメチルアセトフミド (DMAc) 中に抽 る沈殿温度の測定を行った。. Fig. 3 に見られるとおり 楆小点における EVA 共重合体中の土チレン含有率は溶 媒により異なった。 


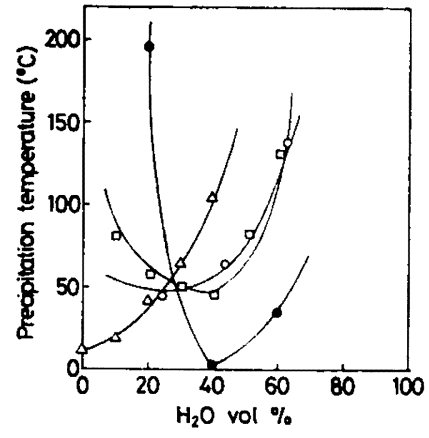

Fig. 2. Relationship between precipitation temperature for EVA coplymers (EVA-33) and water content in aqueous organic solvents: $\triangle$, dimethyl sulfoxide; $\square$, dimethyl formamide; $O$, methanol; , n-propanol.

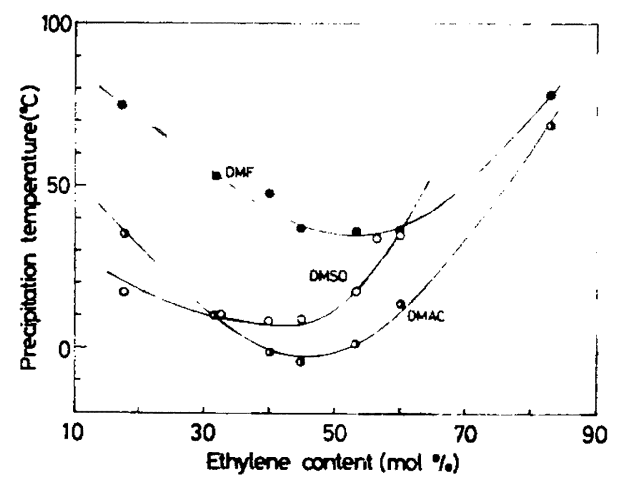

Fig. 3. Precipitation temperature of EVA copolymers with different ethylene contents in organic solvents.

以上の結果を EVA 共重合体に対する溶媒瀷定の参考 にしたささらに次に掍げた諸性質も考虑に入れた。

（1）凝固液（水）に可溶である.

（2）得られた EVA 共画合体膜が機城的性質，およ び透過性能において血液遁析蹎としての要件を满足す 万.

(3) 人体に対して無毒である。

(4) 安洒に入手可能である.

3.2 在んの溶葉から得られた EVA 共百合体䀧の性 iti

Fig. 1 に示した EVA 共重合体が空温で可溶な領域 に属する溶某, および $35^{\circ} \mathrm{C}$ 以上で可溶な溶媒の中から EVA 共重合体透析膜を得るための最適の溶媒を探索し た.ここに用いた EVA 共重合体のエチレン含有量は $18 \sim 85 \mathrm{~mol} \%$ で，凝固液には凝固温度が $-1^{\circ} \mathrm{C}$ の飽和 芒硝水溶液を用いた，EVA-33 について種々の溶媒か

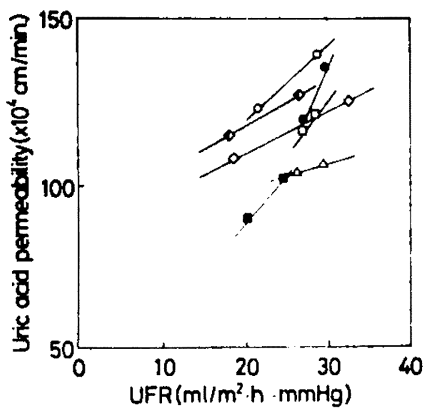

Fig. 4. Effect of various solvents of EVA copolymer (EVA-33) on permeability: $O$, DMSO; , 2-pyrrolidone; $\diamond$, dimethylacetamide; $\diamond$, dimethylacetamide $/ \mathrm{H}_{2} \mathrm{O}(80 / 20$ by vol); $\square$, DMSO/MeOH (80/20 by vol); $\square$, DMSO/MeOH (50/50 by vol); $\Delta, n$-methyl-2pyrrolidone.

ら凝固させて得られる膜の透過特性を調へた，Fig. 4 に良好な透過特性を示す溶媒系について尿酸透過性と透 水性 (UFR) の関係を示した. メタクレゾール，ギ酸， フェノールから得られる EVA 膜の透過性は注とんどぜ 口であり, メタノール/水，n-プロパール/水の混合溶 媒を用いた博合は，透過性能は著しく低い，ゆえに，優 れた性能を有する EVA 透析膜を得るには，DMSO， ピロリトン，DMAC，これらと水，あるいはアルコー ルなどとの混合溶媒のように，Fig. 1 において DMSO の近傍に位斛する溶媒を用いるのが望ましいことが分か ろ. 又，血液透析膜として用いるには前述したように， 透水性と溶筫透過性のつり合いが重要で，例えば，透水 が同じ值の場合には，溶質透過性が大きいほど透析膜と して好ましいといえる。 したがって，Fig. 4 の結果か らエチレン含有量が 33 mol\% の EVA 共重合体の場合 は, DMSO が溶媒としていちばん望ましいことが明ら かである. DMSO は比較的性が低く，水に極めて易 溶性であることも製膜の溶媒に浐している，沈股温度が DMSO より低く，EVA 共重合体に対してより良溶媒

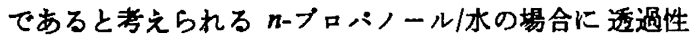
が多った理由については後述する。

Fig. 3 の結果から明らかなよらに，エチレン含有量 により溶媒に对する沈殿温度が異なったが，相対的に沈 殿温度が低いDMSO とジメチルアセトアミドを溶媒に 用いたときの EVA 共重合体中のエチレン含有量の透過 性に及ぼす影暨を Table 1 に示した。この結果から血 液透析膜としての尿酸透過性と透水性のつり合いは EVA-45 の方が EVA-33 よりも良好であることが分 かる.これらを溶媒に用いた場合，エチレン含有胃が $45 \mathrm{~mol} \%$ 付近で沈股温度が極小になることを既に示し た. ゆ卡, DMSO, DMAC は EVA-33 に比較して 
Table 1. Effect of solvent and ethylene content of EVA copolymers on permeabilities

\begin{tabular}{ccccc}
\hline \hline No. & $\begin{array}{c}\text { Ethylene content } \\
(\text { mol } \%)\end{array}$ & Solvent & \multicolumn{2}{c}{ Permeabilities } \\
\cline { 3 - 5 } & 33 & Dimethylsulfoxide & $\begin{array}{c}\text { Uric acid } \\
\left(\times 10^{4} \mathrm{~cm} / \mathrm{min}\right)\end{array}$ & $\begin{array}{c}\text { UFR } \\
\left(\mathrm{m} l / \mathrm{m}^{2} \cdot \mathbf{h} \cdot \mathrm{mmHg}\right)\end{array}$ \\
\hline 1 & 45 & 135 & 16.5 \\
3 & 18 & 145 & 13.0 & 8.0 \\
4 & 33 & Dimethylacetamide & 86 & 8.2 \\
5 & 45 & 100 & 112 & 7.1 \\
6 & 18 & $n$ & 12 & 3.2 \\
\hline
\end{tabular}

EVA-45 に対してより 良容媒であるために，凝固の過 程において EVA-45 が EVA-33 よりも䌅僈に颀固し より均筫な微細檴造の膜が形成されたためであると考え られる.一方, EVA-18 は EVA-45 よりも沈殷温度が 高いにもかかわらず，尿酸透過性と透水性のつり合いが 作れている、これは、 EVA 中のポリビニルフルコール のモル分事の增加により，水とポリマーの水来結合によ る相互作用が大きくなったためであると推定されよう．

以上のよ5に，容筫透過性と透水性の人工堅㬴透析膜 としてのつり合いは, EVA-18 が最良で EVA-45, EVA-33 の順であった。しかし，EVA-18は，後述す ろが，機械的強度が低い，又，膜の保存安定珄について は EVA-33 が EVA-45 よりむ良好であった11.これ らの結果から，EVA-33 を用いて，血液透析膜として の基嗼的検討を行った.

\subsection{DMSO を溶媒として 得られる EVA 共臬合体 陵の性留}

EVA 共重合体を案材として優れた性能を有する血液 透析獏を得るには，溶媒に DMSO，ポリマーに EVA33 を用いるのが望ましいことを前節で明らかにした。 そこで，EVA 共重合体の制膜条件の膜珄能に及ほすす影 呢をより詳しく検尉した，Fig. 5 に凝固温度とボりマ

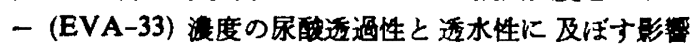
について示した，濑固温度が高くなると透水性は大きく なる傾向にあるが，尿酸の透遇性は反対に低下する㑯问 にあった，血液透析膜として一般に用いられているキュ プロファン膜の透水性は $6 \sim 10 \times 10^{-16} \mathrm{~cm}^{2}$ であり， EVA 共重合体膜はこれと比較して，透水性は非常に高 い.しかし，遁水性をあらかじめ適当に制御しておかな ければ，実用時に透水性の制御が困難であること，およ び透水性と溶質透過性とのつり合いを考虑すると，低温 凝固で，ボリマー激度は 20〜25 wt\% が望ましい.

Fig. 6 にDMSO を溶媒として製膜機を用いて得ら れた EVA-33 膜の透過性に批ける溶留の分子量依存性 をキュプロフフン膜と比較して示した，EVA 共重合体 膜はキュプロフォン膜に比べて，分子量依存性が小さ く，尿恝症の原因物質とされている中分子量領域の透過

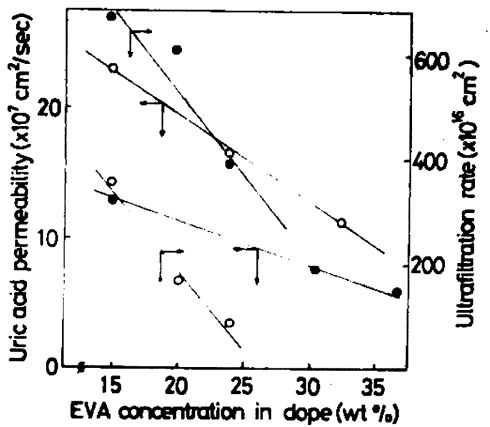

Fig. 5. Effect of EVA-33 concentration and coagulation temperature on permeability. Coagulation temp.: $\mathrm{O}, 2^{\circ} \mathrm{C} ; 0,17 \sim 19^{\circ} \mathrm{C}$. Dope temp., $17 \sim 20^{\circ} \mathrm{C}$.

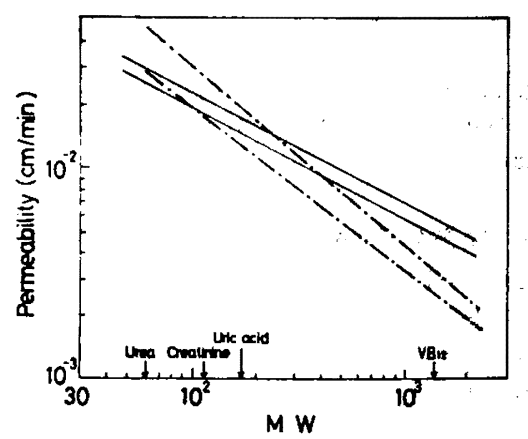

Fig. 6. Permeabilities of different molecular weight substances for EVA copolymer (EVA33) membranes prepared by casting machine and Cuprophan membranes: —, standard EVA (EVA-33) membrane (UFR, 12 18 $\mathrm{ml} / \mathrm{m}^{2}$. h. mmHg); - - C Cuprophan (UFR, 2.8 3.0 mll $\mathrm{m}^{2} \cdot \mathrm{h} \cdot \mathrm{mmHg}$ ).

性が高く，かつ透水性む传れて括り，血液透析謨として 好ましい透過性を有する。 
エチレンーピニルアルコール共重合体からなる人工督腈用透析膜の㱔膜条件と膜性能の検璟

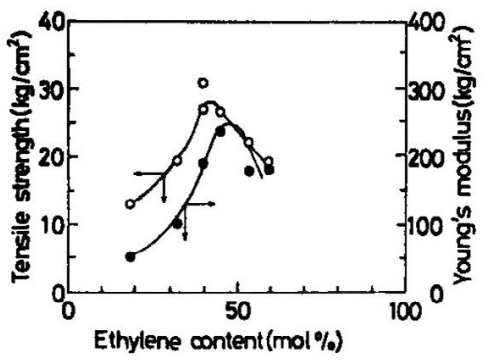

Fig. 7. Effect of ethylene content in EVA copolymer membranes on mechanical properties.

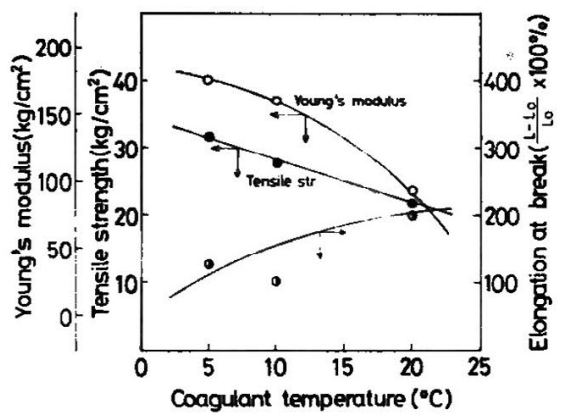

Fig. 8. Effect of coagulant temperature on mechanical properties of EVA-33 wet membranes.

\subsection{EVA 共重合体膜の機械的性質}

EVA 共重合体中のエチレン含有量と平衙含水状態に ある EVA 共重合体膜の機械的性質の関俰を Fig. 7 K 示した. エチレン含有量が $40 \sim 50 \mathrm{~mol} \%$ の膜の破断強 度, ヤング索は良好であるが，50 mol\% 以上になると 膜がもろくなる傾向がみられた。この機械的性質と前述 の透過性の結果から，血液透析膜に䔔した EVA 共重合 体中のエチレン含有量は $30 \sim 45 \mathrm{~mol} \%$ であると考えら れる.

次に，凝固温度が平衝膨潤状晁にある含水 EVA 共重 合体の機械的性質に及活寸影䇺を Fig. 8 に示した. 凝 固温度が低いほど，含水膜の機械的性質は良好である。

叉，含水膜をアセトン省換 して得られる乾燥状怨の EVA 共重合体膜の機械的性質も，低温凝固系で得た膜 の方が高温凝固の膜に比㜞して優れていた，低温凝固系 の膜が後れた機械的性質を示寸理由は，その微細構造に 起因していると考えられ，これについては後述する.

著者らは前報1で，ポリビニルフルコール膜の平衡膨 潤時の破断強度が優れている反面，ナンダ率が小さいこ とを認めたが，本報告では反対の結果が得られた。すな わら, 平衡膨潤時の破断強度は, ポリビニルフルコール 膜はどには優れていないが，ヤング率においては明らか

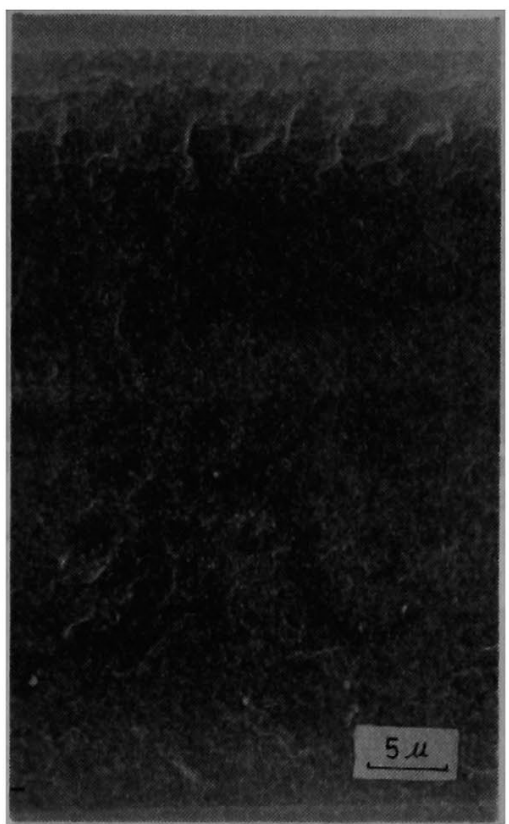

Fig. 9. Scanning electron micrograph of EVA membrane (casting machine): dope concn., 20 wt $\%$, coagulation temp., $4^{\circ} \mathrm{C}$; solvent, DMSO.

に勝っている.人工膩用透析膜として利用する時に，血 液あるいは透析液の流れの妨け゚にならないためには，膜 の破断强度よりもむしろ，ヤング窈の大きさを考虑すべ きである.この点, EVA 膜は血液透析膜として好まし い機械的性質を有していると考えられる，又，乾燥時の 引き裂き強度も血液透析膜にとって重要な因子であり, 本報では示さなかったが EVA 共重合体膜はこの点で もキュフィファン膜よりも優れていだ1).

\subsection{EVA 共重合体膜の徽細搆造}

DMSO を溶媒に用いて種々の凝固温度で製膜した EVA-33 共重合体膜の電子顕徽鏡写真を Fig. 9 12 に

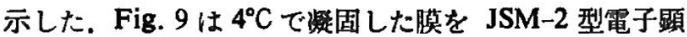
微鏡を用いて，2,400 倍の倍率で断面方向の構造を钼察 したもので, Fig. 10 は HFS-2 型電子顕微鏡を用いて 24,000 倍の倍率で, 膜表面付近の構造を钼察した写真 である. Fig. 9 から低温 $\left(4^{\circ} \mathrm{C}\right)$ で凝固した膜は，2,400 倍の倍率に抋いて膜の断面方向の構造は, 実質的に均質 な構造を有しているよ5にみえる，又，更に倍率を高め て微細構造を観察したころ，膜は粒径 1,000 2,000 の徽小粒子が互いにつながり合った多孔棈造を示し，

(Fig. 10)これらの粒子間げきを通して物質の透過が行 われるるのと推定される，ところが，凝固温度が高くな ると, 膜構造は低温凝固の膜にみられるものとは全く異 なることが分かった．Fig. 11 は $20^{\circ} \mathrm{C} て ゙$ 㠜固した膜を， 


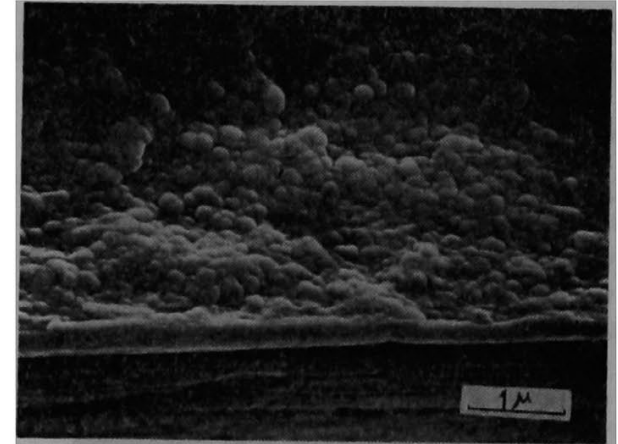

Fig. 10. Scanning electron micrograph of EVA membrane (casting machine): dope concn., 20 wt \%; coagulation temp., $4^{\circ} \mathrm{C}$; solvent, DMSO.

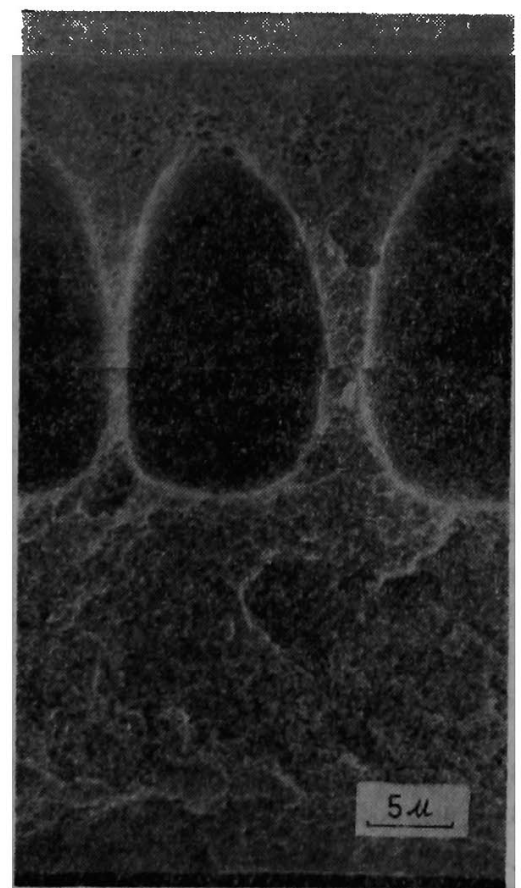

Fig. 11. Scanning electron micrograph of EVA membrane (casting machine): dope concn., 20 wt\%; coagulation temp., $19.7^{\circ} \mathrm{C}$; solvent, DMSO.

JSM-2 型電子䫒微鏡を用いて 2,400 倍の倍率で膜断面 の構造を観察したもので, 高温で㠜固を行うと直径 1 $\mu \mathrm{m}$ 以上の大きな孔が生成した，凝固温度の高い膜では 透水性が大きく，血液透析としての透過性のつり合い や，機械的性質が劣るのはこの構造によるためと考えら れる.

一方, EVA 共重合体の溶媒にメ夕/ール/水 $(70 / 30$

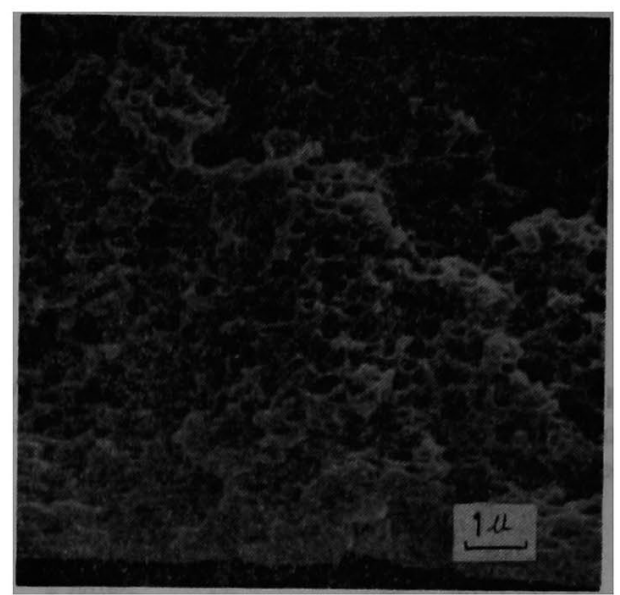

Fig. 12. Scanning electron micrograph of EVA membrane (casting machine): dope concn., 20 wt\%; coagulation temp., $4^{\circ} \mathrm{C}$; solvent, $\mathrm{MeOH} /$ $\mathrm{H}_{2} \mathrm{O}$ (70/30, by vol.).

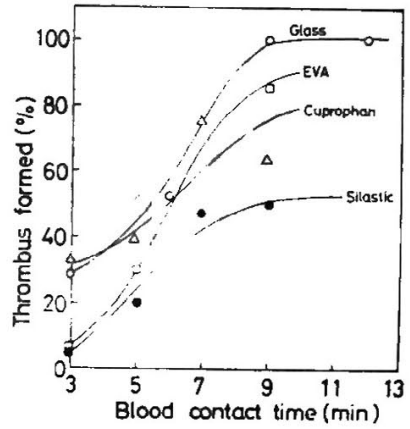

Fig. 13. Anti-thrombogenicity test (in vitro).

容量）の混合溶媒を用いたときの膜表面付近の断面の棈 造を JSM-2 型電子顕微鏡を用いて 8,000 倍に払大し て，测定した結果を Fig. 12 に示した，DMSO を容媒 に用いて得られた膜とは異なり，膜の断面は蜂の雀状の 構造を有しており，両者の微細㨍造は全く異なることが 明らかになった。この写真からは明らかではないが，溶 媒に DMSO を用いた系では凝固が緩慢に進行し，膜表 面に強固な表皮尿が存在せず, 膜全体がち密な構造をと っているが, フルコール系溶媒の場合には凝固が DMSO 系に比較して速く，膜表面に強固な表皮買が形 成され，不均質な膜情造となるために透過性能が劣るる のと考えられる.

\subsection{In vitro での血液適合性試験}

Fig. 13 に犬の ACD 血液を用いた in vitro での抗 凝血性試験の結果を示した. 凝血量値を試料との接触時 間に対して描いたプロットしたもので,この值が小さい 


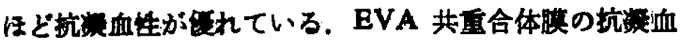
住を既に市肘されている血液透析用のキュブロフフン 膜，医用高分子の中で抗资血性が低れているとされてい る医用シリコーンである Silastic フィルムと比校した。 その結果，EVA 膜の抗濑血性はキュブロフフン膜と同 程度でる。

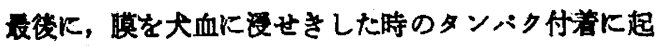
因子る攻办性の低下について検討したところ，透水性の 低下は，エチレン含峌 $33 \mathrm{~mol} \%$ の EVAが $18 \mathrm{~mol} \%$ の EVA より6埴著であった ${ }^{12)}$. 一方キュプロファン 膜では，逐水性のタンホクによる影到はとんど見られ なかったい)、この結果から、 EVA 共重合体倬はキュフ ロファン䀧に比較して透水性が高いが，タンバクの付养 により透水娃が低下する㑯向にあり，in vivo の陚偩で は更化この㑯向が高められることが予想される. したが

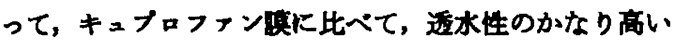
EVA 共重合体獏を政床に用いた均合です，生体からの 除水量を制御するらえで，特にトラブルとならないこと が期待される.

\section{4 括}

（1）血液透析膜として传れた性能を有する EVA 共 重合体膜を得るため，湿式製膜に用いる浴媒探索を溶解 度バラメーター，沈没温度を基にして行い，DMSO が 取良であることを見いたした。

（2）製膜条件は DMSO 溶液の水系人の低温凝固 $\left(5^{\circ} \mathrm{C}\right.$ 以下) が好ましく, 得られた EVA 共重合体透析 膜住，徒来のキュプロファン瞙に比慗して透水性が大き く，尿革应原物筫とされている中分子曋領城の透通 性が传れている. 一方, 高温凝固系 $\left(20^{\circ} \mathrm{C}\right)$ で得られた 膜は，透水性之溶質远過性のつり合い，扣上び機械的性 質が劣っていた。

（3）EVA 共重合体中のエチレン含有量は，透過 性，機械的性貿，保存安定性，血液咅合性などを经合的 に判断して 33 mol\% のものが逗当と考えられる.
（4）ＥVA 共重合体膜は，PVA に比べて破断強度 は低いが，血液道析膜として重要である含水時のヤング 市および䏠煤時の引き裂き強度が但れていた。

（5）EVA-33 共重合体膜の断面棬造を龟子顕微鏡 を用いて貔察した結果，DMSO を溶某に用いた低温凝 固系の膜は，平均径が 1,000 2,000 の徽粒子が互い につながった均萁なミク口多孔梅造を有するが，高温凝 固系の膜は数 $\mu \mathrm{m}$ の大きな孔が存在する不均筫な棈造 を有することが明らかになった。

(6) In vitro における抗凝血性試卧より，EVA 共 重合体膜はキュプロフフン膜と同程度の血液親和性を示 した.

的辞最後に，本研究の発丧を許可下さった(株)ク ラレ中央研究所所長，安井昭夫博士に或䁢します。

\section{文献}

1）山下徏藏，高合孝一，今井应二，增原芙一，就 分子蜦文集, 35, 283 (1978).

2) M. Luttinger and C.W. Cooper, J. Biomed. Mater. Res., 1, 67 (1967).

3) I.O. Salyer et at., J. Biomed. Mater. Res., 6, 59 (1972).

4) 丹沢 宏ら, 人工瞙器, 4, 157 (1975).

5) P. Špačk and M. Kubin, J. Biomed. Mater. Res., 7, 201 (1973).

6) S.K. Brauman and B.K. Fritzinger, J. Appl. Polym. Sci., 16, 2439 (1972).

7) B.S. Fisher et al., Trans. Am. Soc. Artif. Intern. Organs, 19, 429 (1973).

8) Y. Imai and Y. Nosé, J. Biomed. Mater. Res., 6, 165 (1972),

9) C. M. Hansen, Ind. Eng. Chem. Prod. Res. Dev., 8, 2 (1969).

10) B. H. Knox et al., Text. Res. J., 45, 203 (1975).

11）山下攸藏ら，末発表データ。 
Studies on Preparation Conditions and Properties of Ethylene-Vinyl Alcohol Copolymer Membranes for Hemodialysis*

Shuzo Yamashita*1, Shiro Nagata*1, and Koichi TakakuRA*1

*Ethylene-Vinyl Alcohol Copolymer Membranes for Hemodialysis. I.

${ }^{* 1}$ Central Research Laboratories, Kuraray Co., Ltd. (2045-1, Sakazu-Aoeyama, Kurashiki, 710 Japan)

Ethylene-vinyl alcohol (EVA) copolymer membranes prepared by wet coagulation process were investigated for hemodialysis. Various casting solvents and precipitant (water) were tested. The system of dimethyl sulfoxide (solvent) and water (precipitant) was found to be most favorable for making hemodialysis membranes. The membrane properties were considerably influenced by the casting conditions, such as coagulation temperature and polymer concentrations. This membranes cast at a low temperature were characterized by their excellent permeability for water and a middle molecular weight substance, such as vitamine $B_{12}$. Electron microscope revealed a micro-porous structure in which a number of particles having an average diameter of 1,000 to $2,000 \AA$ were bonded with one another.

KEY WORDS Artificial Kidney / Hemodialysis / Membrane / Permeability / Medical Polymer / (Received December 5, 1978: Accepted January 30, 1979)

[Kobunshi Ronbunshu, 36(4), 257-264 (1979)] 